\title{
Share Pledging and Firm Cash Holdings: Evidence From Chinese A-share Listed Firms
}

\author{
Hongmei Xu \\ Correspondence: Hongmei Xu, Department of Finance, College of International Business, South China Normal \\ University, Guangzhou 510631, China.
}

Received: June 23, 2021

doi:10.11114/afa.v7i2.5303

\author{
Accepted: July 8, 2021 \\ Available online: July 22, 2021 \\ URL: https://doi.org/10.11114/afa.v7i2.5303
}

\begin{abstract}
This paper examines the relation between share pledging and cash holdings of Chinese A-share listed-firms. We find that during the years 2005 through 2015, the level of share pledging is negatively associated with cash holdings. We establish causality through a variety of econometric techniques, including a difference-in-differences approach based on a regulatory change that permits security companies to lend money to borrowers pledging their shares as collaterals. In addition, we find that the main effect is more prominent for financial constrained firms, and share pledging is associated with lower cash/investment-cash flow sensitivities and more cash dividend payouts. Overall, our findings indicate that share pledging can alleviate financial constraints of listed firms and reduce their tendencies of holding cash for precautionary motives.
\end{abstract}

Keywords: Share pledge, Corporate cash holdings, financial constraints, difference-in-difference approach

\section{Introduction}

Share pledging, the practice of shareholders use their shares as collaterals to obtain loans, has attracted much attention among academia and practitioners in the last a few years. In this paper, we examine whether share pledging has first-order effect on firm cash holdings. This issue is important, as cash is of vital importance to firms in easing financial frictions and seizing investment opportunities while vulnerable to expropriation by firm insiders due to its liquid nature.

Theoretically, the relation between share pledging and firm cash holdings is ambiguous. On the one hand, share pledging can lead to a decrease in cash holdings. Firms can accumulate cash in order to hedge against operating risks and sustain daily operations. Serving as an additional source of obtaining useful funds, firms will be less financial constrained and therefore hold less cash for precautionary motives if they pledge more shares as collaterals. We term this view the financial constraint channel.

On the other hand, a positive relation could exist. Controlling shareholders with pledged shares may face a margin call threat if stock prices fall below the required level for a loan, and they have an incentive to use corporate resources for their private benefits (Chan et al., 2018). Due to concerns on potential margin calls, firm insiders may choose to hold more cash for precautionary motives.

In addition, share pledging may have no significant effect on firm cash policies. Many times, firm insiders use stocks as collaterals for personal usage, and additional financing to controlling shareholders does not equal to additional financing to the listed firm. Therefore, the practice of pledging shares may have no direct link with firms' cash holding decisions.

Due to these different predictions, whether and how share pledging affects firms' cash holding decisions is an empirical question. In this paper, we build our empirical setting on the Chinese stock market where the ownership structure of listed firms is rather concentrated and the practice of share pledging is pervasive. We begin our research by conducting a regression analysis to examine the association between share pledging and firm cash holdings, and document that on average, one standard deviation increase in share pledging is associated with a $2.4 \%$ decrease in cash holdings.

In the following sections, we take several steps to validate our baseline findings. As certain types of firms are more likely to have their shares pledged (Li et al., 2019), we employ Heckman's (1979) two stage model to address the self-selection issue of pledging shares. The estimation results provide little support for the notion that the observed negative relationship is due to a self-selection problem. 
The CSRC comes up a regulatory change in 2013. By utilizing this regulatory change as a quasi-exogenous shock to share pledging, we can infer a causal effect on firm cash holdings. Based on firm characteristics of the prior year of the regulatory change, we build up a PSM sample (propensity-score matched) and conduct differences-in-differences estimation. Our choice of treatment and control groups resembles prior studies that use decimalization as an exogenous positive shock to stock market liquidity (Fang et al., 2014; Brogaard et al., 2017). i.e., the treatment group consists of firms whose amount of pledged shares increases the most (in the top three deciles of the sample) due to the regulatory change, and the control group includes propensity-score matched firms whose amount of pledge shares increases less but with comparable firm characteristics. Using a differences-in-differences approach, we show that following the regulatory change, an average treatment firm, relative to an average control firm, experiences a $9.0 \%$ decrease in cash holdings, which further suggest a negative causal effect of share pledging on firm cash holdings.

We then conduct several additional tests. We confirm that our main findings are robust to various alternative model specifications and sample selections. We further find that the negative effect of share pledging is more prominent for financial-constrained firms, and firms with more pledged shares have lower cash/investment-cash flow sensitivities and higher level of cash dividend payouts. These results further indicate that share pledging can alleviate financial constraints of firms.

Our paper contributes to several strands of literature. We contribute to the literature on the economic implications of share pledging, which pays much attention on firm value, financial reporting, and executive incentives (Chen and $\mathrm{Hu}$, 2007; Wang and Chou, 2018; Dou et al., 2019; Ouyang et al., 2019). In terms of the real effects of share pledging on firms' investment and financing decisions, Chan et al. (2018) find that firm insiders may initiate share repurchases to fend off potential margin calls associated with pledged stocks. Meng et al. (2019) find that share pledging discourages risk-taking while improves innovation efficiency. We throw additional light on this literature by examining how share pledging affects firms' cash holding decisions. Li et al. (2019) indicate that there is a positive relation between share pledges of the largest shareholder and firm value in China. Our paper provides a specific channel (reducing financial constraints) through which share pledges can increase firm value.

We also contribute to the literature on the determinant of firm cash holdings, particularly the literature that investigates how ownership structures and controlling shareholder motives affects cash holdings (e.g., Dittmar et al., 2003; Megginson et al., 2014). We identify share pledging as an important factor that reduces firms' precautionary motives and therefore discourages cash holdings.

The rest of the paper is organized as follows. Section 2 documents institutional background. Section 3 provides data and empirical design. Section 4 reports main empirical results. Section 5 provides estimation results on further analysis. Section 6 concludes.

\section{Institutional Background}

In China, most listed firms have controlling shareholders, with highly concentrated ownership structures (Jiang and Kim, 2015). To cope with difficulties in obtaining external financing, controlling shareholders pervasively use their owned shares as collateral to borrow money from brokerages, banks, or trust firms. In this way, they can secure credit without altering their control rights (Singh, 2017). However, there are risks associated with pledged shares, as regulators and analysts often warn that share-pledging can amplify a market downturn. When a stock falls in the secondary market and reduces the value of the pledged shares, borrowers have to take out more shares as collateral. Otherwise, they will have to sell shares to pay back the principal. ${ }^{1}$

Both non-SOEs and SOEs can participate in share pledging. As the Chinse credit market is tight, many small and medium-sized non-SOEs have scarce recourse to banks or other sources of financing, and they commonly turn to pledge shares to finance companies as a way of raising cash. ${ }^{2}$ For SOEs, they can pledge shares after getting approved by the State-owned Assets Supervision and Administration Commission (henceforth SASAC). Although possessing advantages in acquiring external financing, SOEs, especially those in capital-intensive industries (i.g. mining, real estate, steel, etc.), also pervasively pledge their shares. In June 2018, among the total 1,024 listed SOEs on the A-share market, 1,020 of them have pledged their shares, which accounts for $12 \%$ of the total value of shares under pledging for the whole market. ${ }^{3}$

\footnotetext{
${ }^{1}$ https://www.scmp.com/business/markets/article/2095530/sell-chinas-pledged-stocks-may-be-double-hong-kongs-gdp.

${ }^{2} \mathrm{https} / / / \mathrm{www}$.reuters.com/article/us-china-markets-stocks-pledged-analysis/slump-persists-china-fails-to-stimulate-mark ets-hobbled-by-pledged-shares-idUSKCN1MY0K8.

${ }^{3}$ http://finance.sina.com.cn/roll/2018-06-27/doc-iheqpwqx7418663.shtml (in Chinese).
} 
The share-pledging loan business on the Chinese stock market has grown quickly. Before 2013, only banks and trust firms can participate in share-pledging activities. On May 24, 2013, the Shanghai Stock Exchange and the ChinaSecurities Depository and Clearing Co., Ltd. publish a rule ("The Guidance on Stock Pledge Repurchase Transactions, Registration, and Settlement") to guide the development of share pledging, permitting security companies to provide finance to borrowers based on pledge shares. ${ }^{4}$ Compared with banks and trust firms, security companies require lower interest rates, have fewer restrictions on the usage of the loans, and approve transactions in a quicker manner. ${ }^{5}$ This regulatory change has prominent real effects on share pledging activities. Since then, the share-pledging loan business has grown even faster. The value of shares pledged has expanded by more than Rmb200bn annually since 2014, according to S\&P, taking the total to Rmb5tn (\$720bn). ${ }^{6}$ The volume of pledged-stock loans surpasses 1 trillion RMB (US\$ 146 billion) in August 2016 and 1.28 trillion RMB (US\$ 188 billion) at the end of 2016, an 81\% increase from $2015 .^{7}$

\section{Data and Empirical Design}

\subsection{Data and Sample Selection}

Our sample consists of Chinese A-share listed firms. The financial variables and stock data spanning from 2005 to 2015 are obtained from the CSMAR Database. We select firm-year observations according to the following procedures. First, according to the classification standard of the CSRC, we exclude observations from the financial industry, which are fundamentally different from non-financial firms. Also, we exclude observations that are in special treatment (ST, *ST, and suspension), as these firms have high distress risk and may behave differently from others. ${ }^{8}$ In addition, all of the continuous main variables are winsorized at the $1 \%$ and $99 \%$ percentiles in order to alleviate the impact of outliers. Our final sample consists of 20,644 firm-year observations.

\subsection{Variable Measurement}

Following previous studies (e.g. Opler et al., 1999; Foley et al., 2007; Harford et al., 2008; Chen et al., 2014), we define the main dependent variable of cash holdings based on Cash, the ratio of cash and cash equivalents to net assets (total assets minus cash and cash equivalents). The main dependent variable, $\log (\mathrm{Cash})$, is then calculated as the logarithm of Cash. One of the major advantages of taking the logarithm transformation is to smooth the distribution of cash holdings and prevent the results from being influenced by outliers (Bates et al., 2009). We also employ several alternative measures for robustness.

According to a CSRC requirement, firms should make announcements when their large shareholders (i.e., persons with more than 5\% shareholdings) pledge their shareholdings for loans, making our setting well-suited for a study on the economic impacts of share pledging. ${ }^{9}$ Accordingly, we construct the primary measure of share pledging, Pledge, as the amount of shares pledged by controlling shareholders as a percentage of total shares. We also construct an indicator variable, Pledge_Dummy, which measures whether the firm involved in share pledging.

In line with prior studies on firm cash holdings (e.g. Chen et al., 2012; Xu et al., 2016), we include a vector of control variables in the baseline model, including firm size, leverage, age, market-to-book ratio, operating cash flow, sales growth, capital expenditure, cash flow volatility, dividend payout, and ownership concentration. We provide detailed definition on these variables in Table A.1 in the Appendix.

\subsection{Empirical Design}

To examine the impact of share pledging on firm cash holdings, we estimate the following equation:

$$
\log (\text { Cash })_{i t}=\beta_{0}+\beta_{1} \text { Pledge }_{i t}+\gamma \text { Control }_{i t}+f_{i}+\tau_{t}+\varepsilon_{i t}
$$

where $i$ indexes firm and $t$ indexes year. The coefficient on Pledge, $\beta_{l}$, is the one with main interest. We also control for firm- $\left(f_{i}\right)$ and year- $\left(\tau_{t}\right)$ fixed effects as well as a vector of control variables in the model and cluster standard errors at the firm level.

\footnotetext{
${ }^{4}$ http://www.sse.com.cn/lawandrules/sserules/trading/stock/c/c_20150906_3976433.shtml (in Chinese).

${ }^{5} \mathrm{http}: / / \mathrm{www}$. infzm.com/content/137459 (in Chinese).

${ }^{6} \mathrm{https}: / /$ www.ft.com/content/a342e01a-d758-11e8-a854-33d6f82e62f8.

${ }^{7}$ https://www.caixinglobal.com/2018-01-15/regulators-limit-pledged-stock-loans-101197973.html.

${ }^{8}$ According to the rule of the CSRC, if a listed firm reports a net loss (below-zero return on equity) for two consecutive years, it will be treated as a special treatment (ST) firm; If the firm continues to make losses for one more year, it will be treated as a particular special treatment $(* \mathrm{ST})$ firm. My main results still hold if I keep these observations in the sample.

${ }^{9}$ http://www.csrc.gov.cn/pub/newsite/flb/flfg/bmgz/ssl/201012/t20101231_189729.html (in Chinese).
} 


\subsection{Summary Statistics}

We report summary statistics of main variables in Table 1 . The mean (median) value of Cash is 0.177 (0.132). The mean (median) value of $\log (\mathrm{Cash})$ is $-1.879(-1.886)$, which is close to the mean (median) of $-1.933(-1.865)$ reported by Xu et al. (2016) based on Chinese listed firms from 1998 through 2014. In addition, the mean (median) value of Pledge is 0.077 (0.000). The mean (median) value of Pledge_Dummy is $0.388(0.000)$, indicating that share pledging occurs in around 40 percent of the firm-year observations.

Table 1. Summary Statistics of the Main Variables

\begin{tabular}{|c|c|c|c|c|c|c|}
\hline & $\begin{array}{l}\text { Num } \\
\text { (1) }\end{array}$ & $\begin{array}{l}\text { Mean } \\
(2)\end{array}$ & $\begin{array}{l}\text { Sd. } \\
(3)\end{array}$ & $\begin{array}{l}\text { P25 } \\
(4) \\
\end{array}$ & $\begin{array}{l}\text { Median } \\
\text { (5) }\end{array}$ & $\begin{array}{l}\text { P75 } \\
(6) \\
\end{array}$ \\
\hline Cash & 20,644 & 0.177 & 0.148 & 0.073 & 0.132 & 0.234 \\
\hline $\log ($ Cash $)$ & 20,644 & -1.879 & 1.133 & -2.543 & -1.886 & -1.188 \\
\hline Pledge & 20,644 & 0.077 & 0.132 & 0.000 & 0.000 & 0.114 \\
\hline Pledge_Dummy & 20,644 & 0.388 & 0.487 & 0.000 & 0.000 & 1.000 \\
\hline Size & 20,644 & 21.738 & 1.248 & 20.868 & 21.601 & 22.442 \\
\hline Leverage & 20,644 & 0.465 & 0.244 & 0.286 & 0.461 & 0.624 \\
\hline $\log ($ Age $)$ & 20,644 & 1.984 & 0.854 & 1.386 & 2.197 & 2.639 \\
\hline$M B$ & 20,644 & 2.159 & 2.068 & 0.823 & 1.529 & 2.716 \\
\hline Opcf & 20,644 & 0.044 & 0.082 & 0.003 & 0.044 & 0.088 \\
\hline Gsale & 20,644 & 0.124 & 0.347 & -0.025 & 0.112 & 0.253 \\
\hline Capex & 20,644 & 0.058 & 0.056 & 0.017 & 0.041 & 0.080 \\
\hline Cf_Sigma & 20,644 & 0.103 & 0.031 & 0.081 & 0.101 & 0.118 \\
\hline Div & 20,644 & 0.574 & 0.494 & 0.000 & 1.000 & 1.000 \\
\hline Top1 & 20,644 & 0.364 & 0.155 & 0.241 & 0.343 & 0.477 \\
\hline
\end{tabular}

This table reports the summary statistics of the main variables used in our regressions estimated by the full sample that consists of firm-year observations. Columns (1) through (6) report the summary statistics of the variables in the full sample. Variable definitions are provided in Table A.1 in this Appendix.

In Table 2, we report correlation matrix of main variables. $\log (\mathrm{Cash})$ is negatively correlated with Pledge, suggesting that firms with more pledged shares tend to have lower cash holdings. As these findings do not control for other possible covariates, we lay our conclusion based on multiple regressions.

Table 2. Correlation Matrix

\begin{tabular}{|c|c|c|c|c|c|c|c|c|c|c|c|c|}
\hline & $\log ($ Cash $)$ & Pledge & Size & Leverage & $\log ($ Age $)$ & $M B$ & Opcf & Gsale & Capex & Cf_Sigma & Div & Top1 \\
\hline Log(Cash) & 1.00 & & & & & & & & & & & \\
\hline Pledge & $-0.14 * * *$ & 1.00 & & & & & & & & & & \\
\hline Size & $-0.16^{* * *}$ & -0.01 & 1.00 & & & & & & & & & \\
\hline Leverage & $-0.48 * * *$ & $\begin{array}{l}0.09 * * \\
*\end{array}$ & $\begin{array}{l}0.25 \\
* * *\end{array}$ & 1.00 & & & & & & & & \\
\hline $\log ($ Age $)$ & $-0.37 * * *$ & $\begin{array}{l}0.08 * * \\
*\end{array}$ & $\begin{array}{l}0.27 \\
* * *\end{array}$ & $0.40 * * *$ & 1.00 & & & & & & & \\
\hline$M B$ & & & -0.4 & & & & & & & & & \\
\hline & $0.24 * * *$ & 0.01 & $\begin{array}{l}5^{* *} \\
*\end{array}$ & $-0.30 * * *$ & $-0.20 * * *$ & 1.00 & & & & & & \\
\hline Opcf & $0.13 * * *$ & $\begin{array}{l}-0.07 * * \\
*\end{array}$ & $\begin{array}{l}0.06 \\
* * *\end{array}$ & $-0.12 * * *$ & $0.02 * * *$ & $\begin{array}{l}0.08^{*} \\
* *\end{array}$ & 1.00 & & & & & \\
\hline Gsale & $0.09 * * *$ & 0.00 & $\begin{array}{l}0.08 \\
* * *\end{array}$ & $-0.03 * * *$ & $-0.09 * * *$ & $\begin{array}{l}0.04 * \\
* *\end{array}$ & $\begin{array}{l}0.07 * \\
* *\end{array}$ & 1.00 & & & & \\
\hline Capex & 0.00 & $\begin{array}{l}-0.05 * * \\
*\end{array}$ & $\begin{array}{l}0.04 \\
* * *\end{array}$ & $-0.12 * * *$ & $-0.24 * * *$ & $\begin{array}{l}-0.02 \\
* * *\end{array}$ & $\begin{array}{l}0.17 * \\
* *\end{array}$ & $\begin{array}{l}0.09 * * \\
*\end{array}$ & 1.00 & & & \\
\hline Cf_Sigma & $0.19 * * *$ & $\begin{array}{l}0.06^{* *} \\
*\end{array}$ & $\begin{array}{l}-0.1 \\
3 * * \\
*\end{array}$ & $-0.13 * * *$ & $-0.07 * * *$ & $\begin{array}{l}0.12 * \\
* *\end{array}$ & $\begin{array}{l}-0.09 \\
* * *\end{array}$ & $\begin{array}{l}0.03 * * \\
*\end{array}$ & $\begin{array}{l}-0.08^{* *} \\
*\end{array}$ & 1.00 & & \\
\hline Div & $0.16^{* * *}$ & $\begin{array}{l}-0.02 * * \\
*\end{array}$ & $\begin{array}{l}0.14 \\
* * *\end{array}$ & $-0.22 * * *$ & $-0.13 * * *$ & $\begin{array}{l}-0.01 \\
* * *\end{array}$ & $\begin{array}{l}0.09 * \\
* *\end{array}$ & $\begin{array}{l}0.03 * * \\
*\end{array}$ & $\begin{array}{l}0.13 * * \\
*\end{array}$ & $0.07 * * *$ & 1.00 & \\
\hline Top1 & 0.00 & $\begin{array}{l}-0.01 * * \\
*\end{array}$ & $\begin{array}{l}0.25 \\
* * *\end{array}$ & $0.00 * * *$ & $-0.09 * * *$ & $\begin{array}{l}-0.10 \\
*\end{array}$ & $\begin{array}{l}0.07 * \\
* *\end{array}$ & $\begin{array}{l}0.06 * * \\
*\end{array}$ & $\begin{array}{l}0.05 * * \\
*\end{array}$ & $-0.09 * * *$ & $\begin{array}{l}0.10 \\
* * *\end{array}$ & 1.00 \\
\hline
\end{tabular}

This table reports a Pearson correlation matrix of variables used in the baseline regression. Variable definitions are provided in Table A.1 in Appendix. Coefficients marked with *, $* *$, and $* * *$ are significant at $10 \%, 5 \%$, and $1 \%$, respectively. 


\section{Empirical Specification and Results}

\subsection{Baseline Results}

In Table 3, we report estimation results on the relation between share pledging and firm cash holdings. In Column (1), we find the coefficient of Pledge is significantly positive, indicating that share pledging is associated with a higher level of cash holdings. In Column (2), we add a series of control variables in the model. The coefficient on Pledge is positive and significant at the 5\% level. In terms of economic significance, a one standard deviation increase in share pledging is associated with a $2.4 \%\left(=1-\mathrm{e}^{-0.180^{*} 0.132}\right)$ decrease in cash holdings. That is, for an average firm with 5,920 million RMB total net assets and 0.177 Cash in our sample, this effect corresponds to a reduction in cash holdings of 25.15 $\left(=5,920 * 0.177 * 2.4 \%\right.$ ) million RMB (or US $\$ 3.76$ million). ${ }^{10}$ These results indicate that a higher level of share pledging is associated with lower cash holdings.

Table 3. Share Pledging and Firm Cash Holdings

\begin{tabular}{|c|c|c|}
\hline & \multicolumn{2}{|l|}{$\log ($ Cash $)$} \\
\hline & (1) & (2) \\
\hline Pledge & $\begin{array}{l}-0.810^{* * * *} \\
(0.103)\end{array}$ & $-0.180^{* *}$ \\
\hline Size & & $\begin{array}{l}0.054 * * \\
(0.025)\end{array}$ \\
\hline Leverage & & $\begin{array}{l}-1.551 * * * \\
(0.091)\end{array}$ \\
\hline $\log (A g e)$ & & $\begin{array}{l}-0.886^{* * *} \\
(0.027)\end{array}$ \\
\hline$M B$ & & $\begin{array}{l}0.052 * * * \\
(0.008)\end{array}$ \\
\hline Opcf & & $\begin{array}{l}1.453^{* * *} \\
(0.103)\end{array}$ \\
\hline Gsale & & $\begin{array}{l}0.069 * * * \\
(0.022)\end{array}$ \\
\hline Capex & & $\begin{array}{l}-0.607 * * * \\
(0.152)\end{array}$ \\
\hline Cf_Sigma & & $\begin{array}{l}0.815^{* *} \\
(0.367)\end{array}$ \\
\hline Div & & $\begin{array}{l}0.079 * * * \\
(0.016)\end{array}$ \\
\hline Top1 & & $\begin{array}{l}-0.124 \\
(0.140)\end{array}$ \\
\hline Firm $F E$ & Y & Y \\
\hline Year FE & Y & Y \\
\hline$N$ & 20,848 & 20,644 \\
\hline$A d j \_R 2$ & 0.082 & 0.303 \\
\hline
\end{tabular}

This table estimates the effect of share pledging on firm cash holdings. All of the variables are as defined in Table A.1 in this Appendix. The sample period covers the years 2005 through 2015. All of our regressions control for year- and firm-fixed effects. The robust standard errors are clustered at the firm level. Robust standard errors are reported in parentheses. The coefficients marked with *,**, and *** are significant at $10 \%, 5 \%$, and $1 \%$, respectively.

\subsection{Heckman Two-Stage Approach}

In this section, we address the issue that firms with less cash holdings may self-select to pledge more shares. The first stage of this model is a Probit equation which models the choice of pledging shares with Pledge_Dummy as the dependent variable. In the second step, we include the inverse Mills ratio derived from the first stage alongside Pledge_Dummy and our prior controls. In Column (1), we observe that firms with certain characteristics (i.e. larger size, lower investment, higher payout tendency, and less concentrated ownership) have higher tendency of pledging shares. In Column (2), the coefficient on the inverse Mills ratio is insignificant, suggesting that the self-section issue is not a major concern in our setting. More importantly, the coefficient on Pledge_Dummy is negative and significant at the 1\% level, suggesting that on average, firms with pledged shares have lower level of cash holdings than other firms.

${ }^{10}$ For this calculation, we assume 1RMB equals to 0.149 US\$ (the exchange rate in March 2019). 
Table 4. The Heckman Two-Stage Approach

\begin{tabular}{|c|c|c|}
\hline & $\begin{array}{l}1^{\text {st }} \text { stage } \\
\text { Pledge_Dummy } \\
\text { (1) }\end{array}$ & $\begin{array}{l}2^{\text {nd }} \text { stage } \\
\log (\text { Cash }) \\
\text { (2) }\end{array}$ \\
\hline Pledge_Dummy & & $\begin{array}{l}-0.181 * * * \\
(0.041)\end{array}$ \\
\hline Size & $\begin{array}{l}0.085^{*} \\
(0.044)\end{array}$ & $\begin{array}{l}0.070 * * * \\
(0.026)\end{array}$ \\
\hline Leverage & $\begin{array}{l}-0.220 \\
(0.178)\end{array}$ & $\begin{array}{l}-1.573^{* * *} \\
(0.113)\end{array}$ \\
\hline $\log (A g e)$ & $\begin{array}{l}-0.030 \\
(0.062)\end{array}$ & $\begin{array}{l}-0.296^{* * *} \\
(0.028)\end{array}$ \\
\hline$M B$ & $\begin{array}{l}-0.022 \\
(0.022)\end{array}$ & $\begin{array}{l}0.048 * * * \\
(0.014)\end{array}$ \\
\hline Opcf & $\begin{array}{l}-0.418 \\
(0.537)\end{array}$ & $\begin{array}{l}1.660 * * * \\
(0.258)\end{array}$ \\
\hline Gsale & $\begin{array}{l}0.013 \\
(0.124)\end{array}$ & $\begin{array}{l}0.117 * * \\
(0.057)\end{array}$ \\
\hline Capex & $\begin{array}{l}-1.272^{*} \\
(0.760)\end{array}$ & $\begin{array}{l}-1.947 * * * \\
(0.430)\end{array}$ \\
\hline Cf_Sigma & $\begin{array}{l}0.520 \\
(1.659)\end{array}$ & $\begin{array}{l}1.379 \\
(1.093)\end{array}$ \\
\hline Div & $\begin{array}{l}0.334 * * * \\
(0.105)\end{array}$ & $\begin{array}{l}0.137^{* *} \\
(0.063)\end{array}$ \\
\hline Top1 & $\begin{array}{l}-0.928^{* * * *} \\
(0.318)\end{array}$ & $\begin{array}{l}-0.236 \\
(0.195)\end{array}$ \\
\hline Inverse Mills Ratio & & $\begin{array}{l}2.717 \\
(7.627)\end{array}$ \\
\hline $\begin{array}{l}\text { Year FE } \\
\text { Industry FE } \\
N\end{array}$ & $\begin{array}{l}Y \\
Y \\
20,711\end{array}$ & $\begin{array}{l}\mathrm{Y} \\
\mathrm{Y} \\
20,711\end{array}$ \\
\hline
\end{tabular}

This table estimates the effect of share pledging on firm cash holdings. All of the variables are as defined in Table A.1 in this Appendix. The sample period covers the years 2005 through 2015. All of the regressions control for year- and industry-fixed effects. Robust standard errors are reported in parentheses. The coefficients marked with *,**, and *** are significant at $10 \%, 5 \%$, and $1 \%$, respectively.

\subsection{Differences-in-Differences Approach}

In the above sections, we show that there is a negative relation between share pledging and firm cash holdings. In this section, to further facilitate the identification of a causal relation, we identify a regulatory change in 2013, namely the publication of a guidance rule of share pledging ("The Guidance on Stock Pledge Repurchase Transactions, Registration, and Settlement"), as a quasi-exogenous positive shock to share pledging, and conduct a differences-in-differences (DiD) estimation. This methodology compares the level of cash holdings of a group of treatment firms whose amount of pledged shares increases the most to that of control firms whose amount of pledged shares increases less, before and after the regulatory change which cause a quasi-exogenous shock to share pledging. could be fundamentally different from the rest of the firms

As indicated in Section II, prior to 2013, only banks and trust firms can participate in share-pledging activities. The rule permits security companies to lend money to borrowers using pledged shares as collaterals. As security companies require lower interest rates, have fewer restrictions on the usage of the loans, and approve transactions in a quicker manner, this regulatory change encourages share pledging activities of listed firms.

This regulatory change appears to be a good candidate to generate plausibly exogenous variation in share pledging for at least two reasons. First, it directly affects share pledging while unlikely to directly affect corporate risk-taking. As indicated by the general provision of the rule, the primary goal of the rule is "to regulate share pledging activities, maintain the market order, and protect the legitimate rights and interests of all parties involved in the transaction", which has no direct relation with listed firms' decisions. Second, changes in share pledging surrounding this regulatory change exhibit variation in the cross-section of firms. Hence, examining the change in risk-taking following the change in share pledging due to the publication of the rule provides a quasi-exogenous shock for our tests.

To address the concern that firms with pledged shares may fundamentally different from other firms in the sample, we 
construct a propensity-score matched sample. We start by retaining all observations for treated and control firms in 2012, the year before the regulatory change comes into effect. We then use a logistic model to estimate the probability of being included in the treatment group by using the control variables in the baseline regression as explanatory variables. We match each treated firm to up to two firms in the control group (with replacement) with closest propensity score. Finally, the sample includes and 470 treatment firms and 370 control firms.

The validity of the DiD estimator critically depends on the parallel trend assumption, i.e. the underlying trends in the outcome variable should the same for both groups. Following Fang et al. (2014) and Brogaard et al. (2017), we perform several diagnostic tests to verify that the assumption holds in our setting. We summarize the results of these tests in Table 5 .

Our diagnose tests are four folds. In Panel A, we re-estimate the Probit model used to estimate propensity scores based on the post-match sample, and then compare the estimation results with those obtained from the pre-match sample. Compared with the estimation results on the baseline Probit model in Column (1), the coefficients on all the explanatory variables are not statistically significant in Column (2), suggesting that there are no observable different characteristics exist between the treatment and control groups before the regulatory change. In Panel B, we report the distribution of the propensity scores for the post-match treatment and control groups and their differences. We can see that the distribution of the propensity scores for the two groups is similar, indicating that the two groups' propensity scores line up closely. In Panel C, we conduct a simple univariate test. We calculate the average change of cash holdings before and after the regulatory change for both the treatment and the control groups. We observe that treatment firms have significant lower cash holdings after the regulation, which serves as an overview of mean differences in cash holdings between the treatment and control groups. In Panel D, we report summary statistics on post-match differences. The sample mean of control variables for matched treated and control firms are not significantly different, suggesting that our selection of matching firms is successful.

Table 5. Propensity Score Matching Attached to the Differences-in-Differences Analysis

\begin{tabular}{lll}
\hline Panel A: Pre-match regression and post-match diagnostic regression & $\begin{array}{l}\text { Post-match } \\
\text { Pre-match } \\
(1)\end{array}$ & $(2)$ \\
\hline Size & $-0.448^{* * *}$ & 0.017 \\
& $(0.065)$ & $(0.095)$ \\
Leverage & $1.082^{* * *}$ & 0.109 \\
& $(0.292)$ & $(0.442)$ \\
Log(Age) & $-0.747^{* * *}$ & -0.082 \\
& $(0.089)$ & $(0.131)$ \\
MB & -0.048 & 0.036 \\
& $(0.049)$ & $(0.075)$ \\
Opcf & -0.363 & -0.463 \\
& $(0.723)$ & $(0.987)$ \\
Gsale & $0.311^{* *}$ & 0.270 \\
& $(0.157)$ & $(0.241)$ \\
Capex & $1.590^{*}$ & -0.665 \\
& $(0.953)$ & $(1.378)$ \\
Cf_Sigma & 2.840 & 0.049 \\
& $(2.903)$ & $(4.163)$ \\
Div & 0.030 & 0.115 \\
& $(0.133)$ & $(0.189)$ \\
Top1 & $-0.650^{*}$ & 0.148 \\
& $(0.359)$ & $(0.518)$ \\
Industry FE & $\mathrm{Y}$ & $\mathrm{Y}$ \\
$\boldsymbol{N}$ & 2,127 & 836 \\
Pseudo_R2 & 0.134 & 0.025 \\
\hline
\end{tabular}


Table 5 (Continued)

\begin{tabular}{|c|c|c|c|c|c|c|c|c|}
\hline \multicolumn{6}{|c|}{ Panel B: Estimated propensity score distributions } & \multirow[b]{2}{*}{$\begin{array}{l}\text { Median } \\
\text { (6) }\end{array}$} & \multirow[b]{2}{*}{$\begin{array}{l}\text { P75 } \\
(7)\end{array}$} & \multirow[b]{2}{*}{$\begin{array}{l}\text { Max } \\
(8)\end{array}$} \\
\hline & $\begin{array}{l}\text { Num } \\
(1)\end{array}$ & $\begin{array}{l}\text { Mean } \\
\text { (2) }\end{array}$ & $\begin{array}{l}\text { Sd. } \\
(3)\end{array}$ & $\begin{array}{l}\text { Min } \\
(4) \\
\end{array}$ & $\begin{array}{l}\text { P25 } \\
(5) \\
\end{array}$ & & & \\
\hline Treatment & 470 & 0.382 & 0.166 & 0.063 & 0.257 & 0.372 & 0.506 & 0.768 \\
\hline Control & 370 & 0.370 & 0.164 & 0.064 & 0.247 & 0.353 & 0.496 & 0.764 \\
\hline Difference & - & 0.012 & 0.002 & -0.001 & 0.010 & 0.019 & 0.010 & 0.002 \\
\hline
\end{tabular}

Panel C: Univariate Tests

\begin{tabular}{llll} 
& $\begin{array}{l}\text { Before } \\
(1)\end{array}$ & $\begin{array}{l}\text { After } \\
(2)\end{array}$ & $\begin{array}{l}\text { Difference } \\
(3)\end{array}$ \\
\hline Treatment & -1.589 & -2.078 & $-0.489^{* * *}$ \\
& $(0.028)$ & $(0.030)$ & $(0.041)$ \\
Control & -1.595 & -1.945 & $-0.350^{* * *}$ \\
Diff-in-Diff & $(0.031)$ & $(0.034)$ & $(0.046)$ \\
& & & $-0.139^{* *}$ \\
\hline
\end{tabular}

Table 5 (Continued)

\begin{tabular}{lllll}
\hline Panel D: Post-match differences & $\begin{array}{l}\text { Control } \\
\text { Treated } \\
(\mathbf{1})\end{array}$ & $(\mathbf{2})$ & $\begin{array}{l}\text { t-value } \\
(\mathbf{3})\end{array}$ & $\begin{array}{l}\text { p-value } \\
(\mathbf{4})\end{array}$ \\
\hline Size & 21.59 & 21.56 & 0.46 & 0.65 \\
Leverage & 0.42 & 0.44 & -1.21 & 0.23 \\
Log(Age) & 1.88 & 1.95 & -1.26 & 0.21 \\
MB & 1.61 & 1.54 & 0.80 & 0.42 \\
Opcf & 0.04 & 0.04 & 0.32 & 0.75 \\
Gsale & 0.09 & 0.07 & 0.96 & 0.34 \\
Capex & 0.07 & 0.06 & 0.87 & 0.38 \\
Cf_Sigma & 0.12 & 0.12 & 0.54 & 0.59 \\
Div & 0.68 & 0.62 & 1.85 & $0.07^{*}$ \\
Top1 & 0.35 & 0.35 & 0.56 & 0.57 \\
\hline
\end{tabular}

Panel A presents parameter estimates from the Probit model used to estimate propensity scores for firms in the treatment and control groups. Panel B reports the distribution of estimated propensity scores for the treatment firms, control firms, and the difference in estimated propensity scores post matching. Panel C presents statistics of the post-match differences in propensity score matching attached to the Differences-in-Differences analysis. Column (1) presents the sample average of firm characteristics in the treated group. Column (2) presents the sample average of firm characteristics in the control group. Column (3) presents the t-test value of the differences between Columns (1) and (2). Column (4) presents the significant level of the sample-mean difference test between Columns (1) and (2). Definitions of all of these variables are provided in Table A.1 in this Appendix.

After confirming the validity of our differences-in-differences setting through diagnose tests above, we then test how the regulatory change affect firms' cash holdings, and present estimation results in Table 6. In Column (1), we observe negative and significant coefficient on Treat*Post, indicating that compared with control firms, firms experience larger decreases in the amount of pledged shares reduce cash holdings significantly. To further confirm that the parallel-trend assumption holds in our setting, we present a dynamic test around the regulatory change. Specifically, we replace Post with several alternative dummy variables, D11-12,D13,D14, and D15, which represents year 2011 or 2012, 2013, 2014, and 2015, respectively. We observe that the negative of the effect of regulation emerges only after the launch of the regulation but not before, implying that the plausibly exogenous increase in share pledging triggers the decrease in firm cash holdings. In Columns (3)-(4), we include the control variables and observe similar results. According to estimation results in Column (3), on average, a treatment firm experiences a $9.0 \%\left(=1-\mathrm{e}^{-0.094}\right)$ decrease in cash holdings relative to a control firm following the regulatory change. 
Table 6. Differences-in-Differences Approach

\begin{tabular}{|c|c|c|c|c|}
\hline & $\begin{array}{l}\log (\text { Cash }) \\
\text { (1) }\end{array}$ & (2) & (3) & (4) \\
\hline Treat*Post & $\begin{array}{l}-0.129 * * \\
(0.052)\end{array}$ & & $\begin{array}{l}-0.094 * * \\
(0.046)\end{array}$ & \\
\hline Treat $* D 11-12$ & & $\begin{array}{l}-0.070 \\
(0.059)\end{array}$ & & $\begin{array}{l}-0.070 \\
(0.052)\end{array}$ \\
\hline Treat*D13 & & $\begin{array}{l}-0.191 * * * \\
(0.066)\end{array}$ & & $\begin{array}{l}-0.154 * * \\
(0.065)\end{array}$ \\
\hline Treat $* D 14$ & & $\begin{array}{l}-0.147 * * \\
(0.073)\end{array}$ & & $\begin{array}{l}-0.127^{*} \\
(0.072)\end{array}$ \\
\hline Treat $* D 15$ & & $\begin{array}{l}-0.153^{*} \\
(0.079)\end{array}$ & & $\begin{array}{l}-0.124^{*} \\
(0.071)\end{array}$ \\
\hline Size & & & $\begin{array}{l}0.107 * * \\
(0.054)\end{array}$ & $\begin{array}{l}0.108 * * \\
(0.054)\end{array}$ \\
\hline Leverage & & & $\begin{array}{l}-1.270 * * * \\
(0.184)\end{array}$ & $\begin{array}{l}-1.269 * * * \\
(0.184)\end{array}$ \\
\hline $\log (A g e)$ & & & $\begin{array}{l}-1.039 * * * \\
(0.050)\end{array}$ & $\begin{array}{l}-1.038 * * * \\
(0.050)\end{array}$ \\
\hline MB & & & $\begin{array}{l}0.027 * * \\
(0.013)\end{array}$ & $\begin{array}{l}0.026 * * \\
(0.013)\end{array}$ \\
\hline Opcf & & & $\begin{array}{l}1.251 * * * \\
(0.175)\end{array}$ & $\begin{array}{l}1.257 * * * \\
(0.175)\end{array}$ \\
\hline Gsale & & & $\begin{array}{l}0.058 * \\
(0.035)\end{array}$ & $\begin{array}{l}0.059 * \\
(0.035)\end{array}$ \\
\hline Capex & & & $\begin{array}{l}-0.994 * * * \\
(0.250)\end{array}$ & $\begin{array}{l}-1.000 * * * \\
(0.250)\end{array}$ \\
\hline Cf_Sigma & & & $\begin{array}{l}1.002 \\
(0.677)\end{array}$ & $\begin{array}{l}1.013 \\
(0.677)\end{array}$ \\
\hline Div & & & $\begin{array}{l}0.029 \\
(0.026)\end{array}$ & $\begin{array}{l}0.030 \\
(0.026)\end{array}$ \\
\hline Top1 & & & $\begin{array}{l}-0.424 \\
(0.261)\end{array}$ & $\begin{array}{l}-0.419 \\
(0.262)\end{array}$ \\
\hline Year FE & $\mathrm{Y}$ & $\mathrm{Y}$ & $\mathrm{Y}$ & $\mathrm{Y}$ \\
\hline Firm $F E$ & $\mathrm{Y}$ & $\mathrm{Y}$ & $\mathrm{Y}$ & $\mathrm{Y}$ \\
\hline$N$ & 5,869 & 5,869 & 5,458 & 5,458 \\
\hline$A d j \_R 2$ & 0.116 & 0.116 & 0.360 & 0.360 \\
\hline
\end{tabular}

This table estimates the effect of share pledging on corporate risk-taking based on the differences-in-differences approach. All of the variables are as defined in Table A.1 in this Appendix. The sample period covers the years 2009 through 2015. All of our regressions control for year- and firm-fixed effects. The robust standard errors are clustered at the firm level. Robust standard errors are reported in parentheses. The coefficients marked with *, $* *$, and $* * *$ are significant at $10 \%, 5 \%$, and $1 \%$, respectively.

4.4 Robustness Checks

In this section, we test the robustness of the main finding. Our tests are three folds, we report the results in the following. In Table 7, we control for potential omitted variables by including high-degree fixed effects in the model. Estimation results indicate that our main findings still hold even if taking city-level and industry-level time-variant omitted variables into consideration. 
Table 7. Including High-degree Fixed Effects

\begin{tabular}{|c|c|c|}
\hline & $\begin{array}{l}\log (\text { Cash }) \\
\text { (1) }\end{array}$ & (2) \\
\hline Pledge & $\begin{array}{l}-0.223 * * * \\
(0.086)\end{array}$ & $\begin{array}{l}-0.223 * * * \\
(0.083)\end{array}$ \\
\hline Size & $\begin{array}{l}0.055^{* *} \\
(0.026)\end{array}$ & $\begin{array}{l}0.049 * \\
(0.026)\end{array}$ \\
\hline Leverage & $\begin{array}{l}-1.544 * * * \\
(0.096)\end{array}$ & $\begin{array}{l}-1.537 * * * \\
(0.093)\end{array}$ \\
\hline $\log (A g e)$ & $\begin{array}{l}-0.864 * * * \\
(0.030)\end{array}$ & $\begin{array}{l}-0.840 * * * \\
(0.031)\end{array}$ \\
\hline$M B$ & $\begin{array}{l}0.046^{* * * *} \\
(0.008)\end{array}$ & $\begin{array}{l}0.049 * * * \\
(0.008)\end{array}$ \\
\hline Opcf & $\begin{array}{l}1.448 * * * \\
(0.108)\end{array}$ & $\begin{array}{l}1.438 * * * \\
(0.106)\end{array}$ \\
\hline Gsale & $\begin{array}{l}0.066 * * * \\
(0.023)\end{array}$ & $\begin{array}{l}0.057 * * \\
(0.023)\end{array}$ \\
\hline Capex & $\begin{array}{l}-0.753^{* * *} \\
(0.162)\end{array}$ & $\begin{array}{l}-0.775 * * * \\
(0.166)\end{array}$ \\
\hline Cf_Sigma & $\begin{array}{l}1.118^{* * *} \\
(0.373)\end{array}$ & \\
\hline Div & $\begin{array}{l}0.085 * * * \\
(0.017)\end{array}$ & $\begin{array}{l}0.072 * * * \\
(0.017)\end{array}$ \\
\hline Top1 & $\begin{array}{l}-0.131 \\
(0.150)\end{array}$ & $\begin{array}{l}-0.110 \\
(0.146)\end{array}$ \\
\hline Firm FE & $\mathrm{Y}$ & $\mathrm{Y}$ \\
\hline Year $F E$ & $\mathrm{Y}$ & $\mathrm{Y}$ \\
\hline City ${ }^{*}$ Year FE & $\mathrm{Y}$ & $\mathrm{N}$ \\
\hline Industry*Year FE & $\mathrm{Y}$ & $\mathrm{Y}$ \\
\hline$N$ & 20,607 & 20,607 \\
\hline $\operatorname{Adj} R 2$ & 0.675 & 0.684 \\
\hline
\end{tabular}

This table estimates the effect of share pledging on firm cash holdings when controlling for high-degree fixed effects. All of the variables are as defined in Table A.1 in this Appendix. The sample period covers the years 2005 through 2015. All of our regressions control for year- and firm-fixed effects. The robust standard errors are clustered at the firm level. Robust standard errors are reported in parentheses. The coefficients marked with *,**, and *** are significant at $10 \%$, $5 \%$, and $1 \%$, respectively.

In Table 8, we replace the main measures of share pledging and firm cash holdings by several alternative measures and re-estimate the baseline regression. In Column (1), we use the indicator variable of whether a firm involves in share pledging activities, Pledge Dummy, as the main explanatory variable. In Column (2), we use shares owned by the top 10 largest shareholders as the deflator of total pledged shares and construct Pledge_Top as the main explanatory variable. In Column (3), we do not take the logarithm transformation to the main dependent variable and employ Cash to measure cash holdings. In Column (4), the dependent variable is changes in cash holdings, $\Delta C a s h$, the ratio of (cash and cash equivalents in year $t$ minus cash and cash equivalents in year t-1) to total assets in year $t-1$. Our baseline findings are robust to the above changes. 
Table 8. Alternative Measures

\begin{tabular}{|c|c|c|c|c|}
\hline & $\begin{array}{l}\log (\text { Cash }) \\
(1) \\
\end{array}$ & $(2)$ & $\begin{array}{l}\text { Cash } \\
(3)\end{array}$ & $\begin{array}{l}\text { Cash } \\
(4)\end{array}$ \\
\hline Pledge & & & $\begin{array}{l}-0.022 * * \\
(0.009)\end{array}$ & $\begin{array}{l}-0.043 * * \\
(0.021)\end{array}$ \\
\hline Pledge_Dummy & $\begin{array}{l}-0.063 * * * \\
(0.019)\end{array}$ & & & \\
\hline Pledge_Top & & $\begin{array}{l}-0.124 * * \\
(0.049)\end{array}$ & & \\
\hline Size & $\begin{array}{l}0.055^{* * *} \\
(0.025)\end{array}$ & $\begin{array}{l}0.053 * * \\
(0.025)\end{array}$ & $\begin{array}{l}0.003 \\
(0.003)\end{array}$ & $\begin{array}{l}0.107 * * * \\
(0.006)\end{array}$ \\
\hline Leverage & $\begin{array}{l}-1.553 * * * \\
(0.091)\end{array}$ & $\begin{array}{l}-1.549 * * * \\
(0.091)\end{array}$ & $\begin{array}{l}-0.155^{* * *} \\
(0.010)\end{array}$ & $\begin{array}{l}-0.074 * * * \\
(0.016)\end{array}$ \\
\hline $\log (A g e)$ & $\begin{array}{l}-0.880 * * * \\
(0.027)\end{array}$ & $\begin{array}{l}-0.885 * * * \\
(0.027)\end{array}$ & $\begin{array}{l}-0.155 * * * \\
(0.004)\end{array}$ & $\begin{array}{l}-0.437 * * * \\
(0.012)\end{array}$ \\
\hline$M B$ & $\begin{array}{l}0.052 * * * \\
(0.008)\end{array}$ & $\begin{array}{l}0.052 * * * \\
(0.008)\end{array}$ & $\begin{array}{l}0.005 * * * \\
(0.001)\end{array}$ & $\begin{array}{l}0.017 * * * \\
(0.002)\end{array}$ \\
\hline Opcf & $\begin{array}{l}1.452 * * * \\
(0.104)\end{array}$ & $\begin{array}{l}1.456 * * * \\
(0.103)\end{array}$ & $\begin{array}{l}0.210 * * * \\
(0.012)\end{array}$ & $\begin{array}{l}0.398 * * * \\
(0.026)\end{array}$ \\
\hline Gsale & $\begin{array}{l}0.069 * * * \\
(0.022)\end{array}$ & $\begin{array}{l}0.069 * * * \\
(0.022)\end{array}$ & $\begin{array}{l}-0.007 * * * \\
(0.002)\end{array}$ & $\begin{array}{l}0.098 * * * \\
(0.009)\end{array}$ \\
\hline Capex & $\begin{array}{l}-0.608 * * * \\
(0.152)\end{array}$ & $\begin{array}{l}-0.610 * * * \\
(0.152)\end{array}$ & $\begin{array}{l}-0.238 * * * \\
(0.019)\end{array}$ & $\begin{array}{l}-0.916 * * * \\
(0.048)\end{array}$ \\
\hline Cf_Sigma & $\begin{array}{l}0.834 * * \\
(0.366)\end{array}$ & $\begin{array}{l}0.808 * * \\
(0.367)\end{array}$ & $\begin{array}{l}0.097 * * \\
(0.042)\end{array}$ & $\begin{array}{l}0.094 \\
(0.095)\end{array}$ \\
\hline Div & $\begin{array}{l}0.078 * * * \\
(0.016)\end{array}$ & $\begin{array}{l}0.079 * * * \\
(0.016)\end{array}$ & $\begin{array}{l}0.002 \\
(0.002)\end{array}$ & $\begin{array}{l}-0.129 * * * \\
(0.006)\end{array}$ \\
\hline Top1 & $\begin{array}{l}-0.162 \\
(0.141)\end{array}$ & $\begin{array}{l}-0.140 \\
(0.140)\end{array}$ & $\begin{array}{l}-0.035^{* *} \\
(0.015)\end{array}$ & $\begin{array}{l}-0.141 * * * \\
(0.033)\end{array}$ \\
\hline Year FE & $\mathrm{Y}$ & $\mathrm{Y}$ & Y & $\mathrm{Y}$ \\
\hline Firm $F E$ & $\mathrm{Y}$ & $\mathrm{Y}$ & $\mathrm{Y}$ & $\mathrm{Y}$ \\
\hline$N$ & 20,663 & 20,644 & 20,657 & 20,570 \\
\hline Adj_R2 & 0.304 & 0.303 & 0.392 & 0.366 \\
\hline
\end{tabular}

This table estimates the effect of share pledging on firm cash holdings by using alternative measures of main variables. All of the variables are as defined in Table A.1 in this Appendix. The sample period covers the years 2005 through 2015. All of our regressions control for year- and firm-fixed effects. The robust standard errors are clustered at the firm level. Robust standard errors are reported in parentheses. The coefficients marked with *, **, and *** are significant at 10\%, $5 \%$, and $1 \%$, respectively.

In Table 9, we conduct several other robustness checks. In Column (1), we include special treatment firms in the sample and re-estimate the baseline regression. In Column (2), we adopt a two-way cluster strategy. In Column (3), we exclude firms located in Beijing, Shanghai, and Guangdong where listed firms are clustered.

We further address the issue that some events occur in our sample period may bias our results. In Column (4), we exclude the observations during 2008-2009, as the financial crisis results in significant decreases in stock prices and may induce firms to adjust the amount of pledged shares and cash holdings simultaneously. Chen et al. (2012) indicate that Chinese listed firms experience a large reduction in cash holdings during 2005-2006 when most firms finish. In Column(6), we control for the effect of the split-share reforms. Therefore, to eliminate the effect of the split-share reform, we exclude observations in year 2005 and 2006 and re-estimate the baseline regression in Column (5). In Column (6), we consider the effect of the Labor Contract Law that carries out in 2008, as Cui et al. (2018) argue that labor protection laws significantly labor-intensive firms' cash holdings. Following Ni and Zhu (2017) and Cui et al. (2018), we include an interaction term of labor intensity (Labor) and an indicator variable (Post08) of law enforcement and obtain positive and significant coefficient, that is consistent with Cui et al. (2018). More importantly, our main findings still hold. 
Table 9. Other Robustness Checks

\begin{tabular}{|c|c|c|c|c|c|c|}
\hline & $\begin{array}{l}\text { Log(Cash) } \\
\text { Including } \\
\text { special } \\
\text { treatment } \\
\text { firms } \\
\text { (1) }\end{array}$ & $\begin{array}{l}\text { Two-way } \\
\text { cluster } \\
\text { (2) }\end{array}$ & $\begin{array}{l}\text { Excluding firms in } \\
\text { Beijing, Shanghai, } \\
\text { and Guangdong } \\
\text { (3) }\end{array}$ & $\begin{array}{l}\text { Excluding } \\
\text { 2008-2009 } \\
\text { (4) }\end{array}$ & $\begin{array}{l}\text { Excluding } \\
\text { 2005-2006 } \\
\text { (5) }\end{array}$ & $\begin{array}{l}\text { Controlling for } \\
\text { Labor Contract } \\
\text { Law } \\
\text { (6) }\end{array}$ \\
\hline Pledge & $\begin{array}{l}-0.156^{* *} \\
(0.068)\end{array}$ & $\begin{array}{l}-0.180 * \\
(0.086)\end{array}$ & $\begin{array}{l}-0.159 * * \\
(0.077)\end{array}$ & $\begin{array}{l}-0.144^{*} \\
(0.076)\end{array}$ & $\begin{array}{l}-0.150 * * \\
(0.064)\end{array}$ & $\begin{array}{l}-0.251^{* *} \\
(0.118)\end{array}$ \\
\hline Labor*Post08 & & & & & & $\begin{array}{l}0.065^{* * *} \\
(0.020)\end{array}$ \\
\hline Size & $\begin{array}{l}0.031 \\
(0.026)\end{array}$ & $\begin{array}{l}0.054 * \\
(0.025)\end{array}$ & $\begin{array}{l}0.071 * * \\
(0.029)\end{array}$ & $\begin{array}{l}0.040 \\
(0.025)\end{array}$ & $\begin{array}{l}0.060^{*} \\
(0.031)\end{array}$ & $\begin{array}{l}0.075 * * \\
(0.033)\end{array}$ \\
\hline Leverage & $\begin{array}{l}-1.477 * * * \\
(0.090)\end{array}$ & $\begin{array}{l}-1.551 * * * \\
(0.109)\end{array}$ & $\begin{array}{l}-1.595^{* * *} \\
(0.113)\end{array}$ & $\begin{array}{l}-1.579^{* * *} \\
(0.090)\end{array}$ & $\begin{array}{l}-1.561 * * * \\
(0.118)\end{array}$ & $\begin{array}{l}-1.378^{* * *} \\
(0.128)\end{array}$ \\
\hline $\log (A g e)$ & $\begin{array}{l}-0.889^{* * *} \\
(0.027)\end{array}$ & $\begin{array}{l}-0.886^{* * *} \\
(0.050)\end{array}$ & $\begin{array}{l}-0.873 * * * \\
(0.036)\end{array}$ & $\begin{array}{l}-0.891 * * * \\
(0.030)\end{array}$ & $\begin{array}{l}-0.921^{* * * *} \\
(0.026)\end{array}$ & $\begin{array}{l}-0.715^{* * *} \\
(0.049)\end{array}$ \\
\hline$M B$ & $\begin{array}{l}0.053 * * * \\
(0.008)\end{array}$ & $\begin{array}{l}0.052 * * * \\
(0.016)\end{array}$ & $\begin{array}{l}0.062 * * * \\
(0.011)\end{array}$ & $\begin{array}{l}0.046 * * * \\
(0.009)\end{array}$ & $\begin{array}{l}0.039 * * * \\
(0.009)\end{array}$ & $\begin{array}{l}0.077 * * * \\
(0.013)\end{array}$ \\
\hline Opcf & $\begin{array}{l}1.433 * * * \\
(0.106)\end{array}$ & $\begin{array}{l}1.453 * * * \\
(0.138)\end{array}$ & $\begin{array}{l}1.406 * * * \\
(0.156)\end{array}$ & $\begin{array}{l}1.482 * * * \\
(0.132)\end{array}$ & $\begin{array}{l}1.329 * * * \\
(0.117)\end{array}$ & $\begin{array}{l}1.288^{* * *} \\
(0.134)\end{array}$ \\
\hline Gsale & $\begin{array}{l}0.080 * * * \\
(0.023)\end{array}$ & $\begin{array}{l}0.069 * * \\
(0.025)\end{array}$ & $\begin{array}{l}0.103 * * * \\
(0.032)\end{array}$ & $\begin{array}{l}0.082 * * * \\
(0.025)\end{array}$ & $\begin{array}{l}0.055 * * \\
(0.021)\end{array}$ & $\begin{array}{l}0.095 * * * \\
(0.028)\end{array}$ \\
\hline Capex & $\begin{array}{l}-0.609 * * * \\
(0.151)\end{array}$ & $\begin{array}{l}-0.607 * * * \\
(0.153)\end{array}$ & $\begin{array}{l}-0.396^{*} \\
(0.214)\end{array}$ & $\begin{array}{l}-0.643 * * * \\
(0.188)\end{array}$ & $\begin{array}{l}-0.640^{* * * *} \\
(0.209)\end{array}$ & $\begin{array}{l}-0.069 \\
(0.206)\end{array}$ \\
\hline Cf_Sigma & $\begin{array}{l}0.963 * * * \\
(0.366)\end{array}$ & $\begin{array}{l}0.815^{*} \\
(0.395)\end{array}$ & $\begin{array}{l}0.598 \\
(0.471)\end{array}$ & $\begin{array}{l}0.915^{* *} \\
(0.381)\end{array}$ & $\begin{array}{l}0.951 * * \\
(0.380)\end{array}$ & $\begin{array}{l}0.660 \\
(0.451)\end{array}$ \\
\hline Div & $\begin{array}{l}0.079 * * * \\
(0.016)\end{array}$ & $\begin{array}{l}0.079 * * * \\
(0.018)\end{array}$ & $\begin{array}{l}0.083 * * * \\
(0.016)\end{array}$ & $\begin{array}{l}0.082 * * * \\
(0.016)\end{array}$ & $\begin{array}{l}0.063 * * * \\
(0.015)\end{array}$ & $\begin{array}{l}0.081 * * * \\
(0.020)\end{array}$ \\
\hline Top1 & $\begin{array}{l}-0.132 \\
(0.140)\end{array}$ & $\begin{array}{l}-0.124 \\
(0.148)\end{array}$ & $\begin{array}{l}-0.275^{* *} \\
(0.116)\end{array}$ & $\begin{array}{l}-0.053 \\
(0.111)\end{array}$ & $\begin{array}{l}-0.290^{* *} \\
(0.126)\end{array}$ & $\begin{array}{l}-0.320 \\
(0.199)\end{array}$ \\
\hline Firm FE & Y & Y & $\mathrm{Y}$ & $\mathrm{Y}$ & Y & $\mathrm{Y}$ \\
\hline Year FE & $\mathrm{Y}$ & $\mathrm{Y}$ & $\mathrm{Y}$ & $\mathrm{Y}$ & Y & $\mathrm{Y}$ \\
\hline$N$ & 21,575 & 20,644 & 14,302 & 17,613 & 18,155 & 11,021 \\
\hline Adj_R2 & 0.289 & 0.664 & 0.296 & 0.313 & 0.318 & 0.171 \\
\hline
\end{tabular}

This table estimates the effect of share pledging on firm cash holdings through other robustness checks. All of the variables are as defined in Table A.1 in this Appendix. The sample period covers the years 2005 through 2015. All of our regressions control for year- and firm-fixed effects. The robust standard errors are clustered at the firm level. Robust standard errors are reported in parentheses. The coefficients marked with *, **, and *** are significant at $10 \%, 5 \%$, and $1 \%$, respectively.

\section{Further Analysis}

\subsection{Cross-Sectional Differences}

Lastly, we investigate cross-sectional variation in firm characteristics to find whether such patterns are consistent with our predictions. As we argue that share pledging leads to a reduction in firm risk-taking through alleviating financial constraints, we conjecture that the negative effect of share pledging should be more pronounced for financial constrained firms.

There are several financial constraint indexes (e.g., KZ index, WW index, and HP index, etc.) that are widely used in previous literature. However, Farre-Mensa and Ljungqvist (2016) point out that many popular measures based on accounting data are likely flawed. Also, as most of them are constructed based on U.S. listed firms, one may argue that these popular measures of financial constraints may be not applicable to Chinese listed firms. Therefore, we follow Chen et al. (2012) and use two proxy variables developed by Almeida et al. (2004): firm size and firm age, as larger and older firms are less likely to be financial constrained because they have more collaterals and higher visibility to outside investors.

We report regression results in Table 10. Estimation results show the coefficients on both Pledge*Size and Pledge ${ }^{*} \log ($ Age $)$ are positive and significant, indicating that the negative effect of share pledging on cash holdings concentrate in smaller and young firms (i.e. more constrained firms). These results further indicate that share pledging 
relieves financial constraints of firms and reduces cash holdings.

Table 10. Cross-Sectional Evidence

\begin{tabular}{|c|c|c|}
\hline & $\begin{array}{l}\log (\text { Cash }) \\
(1)\end{array}$ & (2) \\
\hline Pledge* Size & $\begin{array}{l}0.148 * * \\
(0.069)\end{array}$ & \\
\hline Pledge $* \log ($ Age $)$ & & $\begin{array}{l}0.238 * * \\
(0.111)\end{array}$ \\
\hline Pledge & $\begin{array}{l}-3.377^{* *} \\
(1.515)\end{array}$ & $\begin{array}{l}-0.697 * * * \\
(0.233)\end{array}$ \\
\hline Size & $\begin{array}{l}0.037 \\
(0.028)\end{array}$ & $\begin{array}{l}0.050 * * \\
(0.025)\end{array}$ \\
\hline Leverage & $\begin{array}{l}-1.554 * * * \\
(0.091)\end{array}$ & $\begin{array}{l}-1.544 * * * \\
(0.091)\end{array}$ \\
\hline $\log ($ Age $)$ & $\begin{array}{l}-0.878 * * * \\
(0.028)\end{array}$ & $\begin{array}{l}-0.872 * * * \\
(0.028)\end{array}$ \\
\hline$M B$ & $\begin{array}{l}0.052 * * * \\
(0.008)\end{array}$ & $\begin{array}{l}0.051 * * * \\
(0.008)\end{array}$ \\
\hline Opcf & $\begin{array}{l}1.454 * * * \\
(0.103)\end{array}$ & $\begin{array}{l}1.451 * * * \\
(0.103)\end{array}$ \\
\hline Gsale & $\begin{array}{l}0.070 * * * \\
(0.022)\end{array}$ & $\begin{array}{l}0.070 * * * \\
(0.022)\end{array}$ \\
\hline Capex & $\begin{array}{l}-0.601 * * * \\
(0.152)\end{array}$ & $\begin{array}{l}-0.609 * * * \\
(0.152)\end{array}$ \\
\hline Cf_Sigma & $\begin{array}{l}0.836 * * \\
(0.367)\end{array}$ & $\begin{array}{l}0.841 * * \\
(0.366)\end{array}$ \\
\hline Div & $\begin{array}{l}0.078 * * * \\
(0.016)\end{array}$ & $\begin{array}{l}0.080 * * * \\
(0.016)\end{array}$ \\
\hline Top1 & $\begin{array}{l}-0.122 \\
(0.141)\end{array}$ & $\begin{array}{l}-0.128 \\
(0.141)\end{array}$ \\
\hline Firm FE & $\mathrm{Y}$ & $\mathrm{Y}$ \\
\hline Year $F E$ & $\mathrm{Y}$ & $\mathrm{Y}$ \\
\hline $\boldsymbol{N}$ & 20,644 & 20,644 \\
\hline Adj_R2 & 0.303 & 0.303 \\
\hline
\end{tabular}

This table estimates the effect of share pledging on firm cash holdings by exploring cross-sectional differences. All of the variables are as defined in Table A.1 in this Appendix. The sample period covers the years 2005 through 2015. All of our regressions control for year- and firm-fixed effects. The robust standard errors are clustered at the firm level. Robust standard errors are reported in parentheses. The coefficients marked with $*, * *$, and $* * *$ are significant at $10 \%, 5 \%$, and $1 \%$, respectively.

\subsection{The Effect on Cash/Investment-Cash Flow Sensitivity}

In Table 11, to throw additional light on how share pledging affects firm cash holdings, we examine the effect of share pledging on cash/investment-cash flow sensitivities. The effects of the share pledging through the financial constraint channel will reduce the propensity to accumulate cash, as captured by either the investment-to-cash-flow sensitivity measure developed in Fazzari et al. (1988) or the cash-to-cash-flow sensitivity measure developed in Almeida et al. (2004). Evidence results indicate that firms with more pledged shares have lower cash/investment-cash flow sensitivities, suggesting that share pledging can alleviate the financial constraint of firms. 
Table 11. The Effect of Share Pledging on Cash/Investment-cash flow Sensitivity

\begin{tabular}{|c|c|c|}
\hline & $\begin{array}{l}\text { CCash } \\
\text { (1) }\end{array}$ & $\begin{array}{l}\text { Capex } \\
(2) \\
\end{array}$ \\
\hline Pledge*Cashflow & $\begin{array}{l}-0.617 * * * \\
(0.207)\end{array}$ & $\begin{array}{l}-0.077^{*} \\
(0.042)\end{array}$ \\
\hline Pledge & $\begin{array}{l}-0.218^{* * *} \\
(0.022)\end{array}$ & $\begin{array}{l}-0.027^{* * *} \\
(0.004)\end{array}$ \\
\hline Cashflow & $\begin{array}{l}0.766 * * * \\
(0.044)\end{array}$ & $\begin{array}{l}0.086 * * * \\
(0.009)\end{array}$ \\
\hline Size & $\begin{array}{l}0.048^{* * *} \\
(0.005)\end{array}$ & $\begin{array}{l}0.009 * * * \\
(0.001)\end{array}$ \\
\hline$M B$ & $\begin{array}{l}0.007 * * * \\
(0.002)\end{array}$ & $\begin{array}{l}0.001 * * \\
(0.000)\end{array}$ \\
\hline Capex & $\begin{array}{l}-0.819^{* * *} \\
(0.048)\end{array}$ & $\begin{array}{l}1.316^{* * *} \\
(0.012)\end{array}$ \\
\hline$\Delta W k$ & $\begin{array}{l}0.383 * * * \\
(0.023)\end{array}$ & $\begin{array}{l}0.059 * * * \\
(0.005)\end{array}$ \\
\hline$\Delta S d e b t$ & $\begin{array}{l}0.336^{* * * *} \\
(0.020)\end{array}$ & $\begin{array}{l}0.092 * * * \\
(0.005)\end{array}$ \\
\hline Firm FE & $\mathrm{Y}$ & $\mathrm{Y}$ \\
\hline Year $F E$ & $\mathrm{Y}$ & $\mathrm{Y}$ \\
\hline$N$ & 20,624 & 20,624 \\
\hline Adj_R2 & 0.232 & 0.762 \\
\hline
\end{tabular}

This table estimates the effect of share pledging on cash/investment-cash flow sensitivity. All of the variables are as defined in Table A.1 in this Appendix. The sample period covers the years 2005 through 2015. All of our regressions control for year- and firm-fixed effects. The robust standard errors are clustered at the firm level. Robust standard errors are reported in parentheses. The coefficients marked with $*$, $* *$, and $* * *$ are significant at $10 \%, 5 \%$, and $1 \%$, respectively.

\subsection{The Effect on Cash Dividend Payouts}

In Table 12, we examine where the cash goes when the firm reduces cash holdings in view of cash dividend payouts. We conjecture that firms with pledged shares may increase cash dividend payouts in the meantime of reducing cash holdings. To construct dependent variables Div_Asset and Div_Sale, we use total assets and total sales as denominators of cash dividends. The coefficients on Pledge are positive and significant in both columns, indicating that share pledging induces firms to increase cash dividend payouts as a source of reducing cash holdings. As dividend payout is also a measure of financial constraint, the evidence provides further support on that share pledging can alleviate financial constraints of listed firms. 
Table 12. Share Pledging and Cash Dividend Payouts

\begin{tabular}{|c|c|c|}
\hline & $\begin{array}{l}\text { Div_Asset } \\
\text { (1) }\end{array}$ & $\begin{array}{l}\text { Div_Sale } \\
\text { (2) }\end{array}$ \\
\hline Pledge & $\begin{array}{l}0.002^{*} \\
(0.001)\end{array}$ & $\begin{array}{l}0.006^{* *} \\
(0.002)\end{array}$ \\
\hline Size & $\begin{array}{l}0.001 * * * \\
(0.000)\end{array}$ & $\begin{array}{l}0.005 * * * \\
(0.001)\end{array}$ \\
\hline Leverage & $\begin{array}{l}-0.013 * * * \\
(0.001)\end{array}$ & $\begin{array}{l}-0.026^{* * * *} \\
(0.002)\end{array}$ \\
\hline $\log (A g e)$ & $\begin{array}{l}-0.007 * * * \\
(0.000)\end{array}$ & $\begin{array}{l}-0.020^{* * *} \\
(0.001)\end{array}$ \\
\hline MB & $\begin{array}{l}0.001 * * * \\
(0.000)\end{array}$ & $\begin{array}{l}0.001 * * * \\
(0.000)\end{array}$ \\
\hline Opcf & $\begin{array}{l}0.021 * * * \\
(0.002)\end{array}$ & $\begin{array}{l}0.030 * * * \\
(0.003)\end{array}$ \\
\hline Gsale & $\begin{array}{l}0.001 * * * \\
(0.000)\end{array}$ & $\begin{array}{l}-0.003 * * * \\
(0.001)\end{array}$ \\
\hline Capex & $\begin{array}{l}-0.003 \\
(0.002)\end{array}$ & $\begin{array}{l}-0.007 \\
(0.006)\end{array}$ \\
\hline Cf_Sigma & $\begin{array}{l}0.017 * * * \\
(0.005)\end{array}$ & $\begin{array}{l}0.027 * * \\
(0.012)\end{array}$ \\
\hline Top1 & $\begin{array}{l}0.004 * * \\
(0.002)\end{array}$ & $\begin{array}{l}0.007^{*} \\
(0.005)\end{array}$ \\
\hline Firm FE & Y & Y \\
\hline $\begin{array}{l}\text { Year } F E \\
N\end{array}$ & $\begin{array}{l}Y \\
20,692\end{array}$ & $\begin{array}{l}Y \\
20,692\end{array}$ \\
\hline Adj_R2 $R$ & 0.122 & 0.109 \\
\hline
\end{tabular}

This table estimates the effect of share pledging on cash dividend payouts. All of the variables are as defined in Table A.1 in this Appendix. The sample period covers the years 2005 through 2015. All of our regressions control for yearand firm-fixed effects. The robust standard errors are clustered at the firm level. Robust standard errors are reported in parentheses. The coefficients marked with *,**, and *** are significant at $10 \%, 5 \%$, and $1 \%$, respectively.

\subsection{Alternative Explanation}

Lastly, we consider an alternative explanation. Following previous literature (e.g. Chen et al., 2012; Li et al., 2017), we employ two measures of controlling shareholder expropriation. The first one is the divergence between controlling shareholders' voting rights and cash-flow rights (Separation), an increase of which leads to increased entrenchment and tunneling and lower firm value (Claessens et al., 2002; Li et al., 2017). The second one is the product of total shares held by the second to the fifth largest shareholders as a percentage of total shares outstanding and a Herfindahl index for the concentration of shares among these shareholders (Monitor), constructed following Chen et al. (2012). Large shareholders have both the incentive to monitor insiders' behavior and the ability to do so. However, the monitoring effectiveness of large shareholders will be attenuated if there is a free rider problem (Shleifer and Vishny 1986).

We report estimation results in Table 13. If the above explanation holds, we should observe more pronounced effect of share pledging for firms suffer from severer controlling shareholder expropriation (i.e. negative and significant coefficient on Pledge*Separation, and positive and significant coefficient on Pledge*Monitor). However, we fail to observe that the degree of controlling shareholder expropriation makes a difference on the effect of share pledging on firm cash holdings, suggesting that the explanation above is insufficient to explain our main findings. 
Table 13. Alternative Explanation

\begin{tabular}{|c|c|c|c|}
\hline & $\begin{array}{l}\log (\text { Cash }) \\
\text { (1) }\end{array}$ & (2) & (3) \\
\hline Pledge $*$ Separation & $\begin{array}{l}0.006 \\
(0.007)\end{array}$ & & \\
\hline Pledge*Monitor & & $\begin{array}{l}-6.338 \\
(3.981)\end{array}$ & \\
\hline Pledge $*$ SOE & & & $\begin{array}{l}-0.012 \\
(0.162)\end{array}$ \\
\hline Separation & $\begin{array}{l}0.001 \\
(0.002)\end{array}$ & & \\
\hline Monitor & & $\begin{array}{l}1.111 \\
(1.774)\end{array}$ & \\
\hline$S O E$ & & & $\begin{array}{l}0.053 \\
(0.061)\end{array}$ \\
\hline Pledge & $\begin{array}{c}-0.187^{*} \\
(0.101)\end{array}$ & $\begin{array}{c}-0.140^{*} \\
(0.072)\end{array}$ & $\begin{array}{l}-0.167 * * \\
(0.071)\end{array}$ \\
\hline Size & $\begin{array}{l}0.053 * * \\
(0.026)\end{array}$ & $\begin{array}{l}0.053^{* *} \\
(0.026)\end{array}$ & $\begin{array}{l}0.053 * * \\
(0.025)\end{array}$ \\
\hline Leverage & $\begin{array}{l}-1.504^{* * *} \\
(0.091)\end{array}$ & $\begin{array}{l}-1.550^{* * * *} \\
(0.091)\end{array}$ & $\begin{array}{l}-1.553 * * * \\
(0.090)\end{array}$ \\
\hline $\log (A g e)$ & $\begin{array}{l}-0.898^{* * *} \\
(0.028)\end{array}$ & $\begin{array}{l}-0.881^{* * *} \\
(0.026)\end{array}$ & $\begin{array}{l}-0.887^{* * * *} \\
(0.028)\end{array}$ \\
\hline$M B$ & $\begin{array}{l}0.050 * * * \\
(0.008)\end{array}$ & $\begin{array}{l}0.052 * * * \\
(0.009)\end{array}$ & $\begin{array}{l}0.052 * * * \\
(0.009)\end{array}$ \\
\hline Opcf & $\begin{array}{l}1.438 * * * \\
(0.105)\end{array}$ & $\begin{array}{l}1.452 * * * \\
(0.122)\end{array}$ & $\begin{array}{l}1.452 * * * \\
(0.122)\end{array}$ \\
\hline Gsale & $\begin{array}{l}0.066^{* * *} \\
(0.022)\end{array}$ & $\begin{array}{l}0.069 * * * \\
(0.025)\end{array}$ & $\begin{array}{l}0.070 * * * \\
(0.025)\end{array}$ \\
\hline Capex & $\begin{array}{l}-0.548^{* * *} \\
(0.156)\end{array}$ & $\begin{array}{l}-0.610^{* * *} \\
(0.185)\end{array}$ & $\begin{array}{l}-0.603 * * * \\
(0.184)\end{array}$ \\
\hline Cf_Sigma & $\begin{array}{l}0.806^{* *} \\
(0.376)\end{array}$ & $\begin{array}{l}0.820 * * \\
(0.361)\end{array}$ & $\begin{array}{l}0.815^{* *} \\
(0.360)\end{array}$ \\
\hline Div & $\begin{array}{l}0.080 * * * \\
(0.016)\end{array}$ & $\begin{array}{l}0.079 * * * \\
(0.015)\end{array}$ & $\begin{array}{l}0.079 * * * \\
(0.015)\end{array}$ \\
\hline Top1 & $\begin{array}{l}-0.162 \\
(0.147)\end{array}$ & $\begin{array}{l}-0.115 \\
(0.121)\end{array}$ & $\begin{array}{l}-0.128 \\
(0.112)\end{array}$ \\
\hline Firm FE & Y & Y & Y \\
\hline Year FE & Y & Y & Y \\
\hline $\begin{array}{l}N \\
A d j \_R 2\end{array}$ & $\begin{array}{l}19,683 \\
0.303\end{array}$ & $\begin{array}{l}20,644 \\
0.303\end{array}$ & $\begin{array}{l}20,644 \\
0.303\end{array}$ \\
\hline
\end{tabular}

This table examines whether the effect of share pledging on firm cash holdings is consistent with an alternative explantion. All of the variables are as defined in Table A.1 in this Appendix. The sample period covers the years 2005 through 2015. All of our regressions control for year- and firm-fixed effects. The robust standard errors are clustered at the firm level. Robust standard errors are reported in parentheses. The coefficients marked with $*, * *$, and $* * *$ are significant at $10 \%, 5 \%$, and $1 \%$, respectively.

\section{Conclusion}

In this paper, we examine the relationship between share pledging and firm cash holdings. Based on the universe of Chinese listed firms from 2005 through 2015, we find that share pledging is associated with a higher level of cash holdings, and the effect is more pronounced for financial constrained firms. In addition, share pledging is associated with lower cash/investment-cash flow sensitivities and more cash dividend payouts. Our findings indicate that share pledging can alleviate financial constraints of listed firms, which identifies an important channel through which share pledging can increase firm value in the Chinese stock market. 


\section{References}

Allen, F., Qian, J., \& Qian, M. (2005). Law, finance, and economic growth in China. Journal of Financial Economics, 77(1), 57-116. https://doi.org/10.1016/j.jfineco.2004.06.010

Almeida, H., Campello, M, \& Weisbach, M. S. (2004). The cash flow sensitivity of cash. Journal of Finance, 59(4), 1777-1804. https://doi.org/10.1111/j.1540-6261.2004.00679.x

Asija, A., Marisetty, V. B., \& Rangan, S. (2014). Do insiders who pledge their shares manipulate reported earnings?. Working Paper.

Bates, T. W., Kahle, K. M., \& Stulz, R. M. (2009). Why do US firms hold so much more cash than they used to? Journal of Finance, 64(5), 1985-2021. https://doi.org/10.1111/j.1540-6261.2009.01492.x

Cassell, C. A., Huang, S. X., \& Sanchez, J. M. (2012). Seeking safety: The relation between CEO inside debt holdings and the riskiness of firm investment and financial policies. Journal of Financial Economics, 103(3), 588-610. https://doi.org/10.1016/j.jfineco.2011.10.008

Chan, K., Chen, H. K., \& Hu, S. Y. (2018). Share pledges and margin call pressure. Journal of Corporate Finance, 52, 96-117. https://doi.org/10.1016/j.jcorpfin.2018.08.003

Chen, D., Li, S., \& Xiao, J. Z. (2014). The effect of government quality on corporate cash holdings. Journal of Corporate Finance, 27, 384-400. https://doi.org/10.1016/j.jcorpfin.2014.05.008

Chen, H. K., \& Hu, S. (2017). The information content of insider pledging. Working Paper.

Chen, Q., Chen, X., Schipper, K., Xu, Y., \& Xue, J. (2012). The sensitivity of corporate cash holdings to corporate governance. Review of Financial Studies, 25(12), 3610-3644. https://doi.org/10.1093/rfs/hhs099

Chen, S., Sun, Z., \& Tang, S. (2011). Government intervention and investment efficiency: Evidence from China. Journal of Corporate Finance, 17(2), 259-271. https://doi.org/10.1016/j.jcorpfin.2010.08.004

Chen, Y., \& Hu, S. Y. (2007). The controlling shareholder's personal leverage and firm performance. Applied Economics, 39(8), 1059-1075. https://doi.org/10.1080/00036840500462004

Claessens, S., Djankov, S., \& Fan, J. P. H. (2002). Disentangling the incentive and entrenchment effects of large shareholdings. Journal of Finance, 57(6), 2741-2771. https://doi.org/10.1111/1540-6261.00511

Cui, C., John, K., Pang, J., \& Wu, H. (2018). Employment protection and corporate cash holdings: Evidence from China's labor contract law. Journal of Banking \& Finance, 92, 182-194. https://doi.org/10.1016/j.jbankfin.2018.05.011

Dittmar, A., Mahrt-Smith, J., \& Servaes, H. (2003). International corporate governance and corporate cash holdings. Journal of Financial and Quantitative analysis, 38(1), 111-133. https://doi.org/10.2307/4126766

Dou, Y., Masulis, R. W., \& Zein, J. (2019). Shareholder wealth consequence of insider pledging of company stock as collateral for personal loans. Review of Financial Studies. https://doi.org/10.1093/rfs/hhz034

Ekström, E., \& Wanntorp, H. (2008). Margin call stock loans. Working Paper.

Fang, V. W., Tian, X., \& Tice, S. (2014). Does stock liquidity enhance or impede firm innovation?. Journal of Finance, 69(5), 2085-2125. https://doi.org/10.1111/jofi.12187

Farre-Mensa, J., \& Ljungqvist, A. (2016). Do measures of financial constraints measure financial constraints? Review of Financial Studies, 29(2), 271-308. https://doi.org/10.1093/rfs/hhv052

Fazzari, S. M., Hubbard, R. G., \& Petersen, B. C.(1988). Financing constraints and corporate investment. Brookings Papers on Economic Activity, 19(1), 141-206. https://doi.org/10.2307/2534426

Firth, M., Gao, J., \& Shen, J. (2016). Institutional stock ownership and firms' cash dividend policies: Evidence from China. Journal of Banking \& Finance, 65, 91-107. https://doi.org/10.1016/j.jbankfin.2016.01.009

Foley, C. F., Hartzell, J. C., \& Titman, S. (2007). Why do firms hold so much cash? A tax-based explanation. Journal of Financial Economics, 86(3), 579-607. https://doi.org/10.1016/j.jfineco.2006.11.006

Gormley, T. A., \& Matsa, D. A. (2016). Playing it safe? Managerial preferences, risk, and agency conflicts. Journal of Financial Economics, 122(3), 431-455. https://doi.org/10.1016/j.jfineco.2016.08.002

Han, S., \& Qiu, J. (2007). Corporate precautionary cash holdings. Journal of Corporate Finance, 13(1), 43-57. https://doi.org/10.1016/j.jcorpfin.2006.05.002

Harford, J., Mansi, S. A., \& Maxwell, W. F. (2008). Corporate governance and firm cash holdings in the U.S.. Journal of Financial Economics, 87(3), 535-555. https://doi.org/10.1016/j.jineco.2007.04.002 
Hwang, A. L. J., Qiao, Y., \& Ku, C. (2016). Pledge or not pledge? Shares owned by insiders pledged for collateral. Working Paper.

Imbens, G. W., \& Angrist, J. D. (1994). Identification and estimation of local average treatment effects. Econometrica, 62(2), 467-475. https://doi.org/10.2307/2951620

Jiang, F., \& Kim, K. A. (2015). Corporate governance in China: A modern perspective. Journal of Corporate Finance, 32, 190-216. https://doi.org/10.1016/j.jcorpfin.2014.10.010

Kalcheva, I., \& Lins, K. V. (2007). International evidence on cash holdings and expected managerial agency problems. Review of Financial Studies, 20(4), 1087-1112. https://doi.org/10.1093/rfs/hhm023

Keil, J., \& Müller, K. (2016). Do firms pledge their pledgeable assets? Working Paper.

Kusnadi, Y. (2011). Do corporate governance mechanisms matter for cash holdings and firm value?. Pacific-Basin Finance Journal, 19(5), 554-570. https://doi.org/10.1016/j.pacfin.2011.04.002

Li, K., \& Prabhala, N. (2007). Self-selection models in corporate finance. Handbook of corporate finance: Empirical corporate finance, 1,37 .

Li, M., Liu, C., \& Scott, T. (2019). Share pledges and firm value. Pacific-Basin Finance Journal. https://doi.org/10.1016/j.pacfin.2019.04.001

Li, O. Z., Liu, H., Ni, C., \& Ye, K. (2017). Individual investors' dividend taxes and corporate payout policies. Journal of Financial and Quantitative Analysis, 52(3), 963-990. https://doi.org/10.1017/S0022109017000199

Megginson, W. L., Ullah, B., \& Wei, Z. (2014). State ownership, soft-budget constraints, and cash holdings: Evidence from China's privatized firms. Journal of Banking \& Finance, 48, 276-291. https://doi.org/10.1016/j.jbankfin.2014.06.011

Ni, X., \& Zhu, W. The bright side of labor protection in emerging markets: The case of firm transparency. Pacific-Basin Finance Journal, 50, 126-143. https://doi.org/10.1016/j.pacfin.2017.06.009

Opler, T., Pinkowitz, L., \& Stulz, R. (1999). The determinants and implications of corporate cash holdings. Journal of Financial Economics, 52(1), 3-46. https://doi.org/10.1016/S0304-405X(99)00003-3

Ouyang, C., Xiong, J., \& Fan, L. (2019). Do insiders share pledging affect executive pay-for-performance sensitivity?. International Review of Economics \& Finance, forthcoming. https://doi.org/10.1016/j.iref.2018.10.019

Rosenbaum, P. R., \& Rubin, D. B. (1983). The central role of the propensity score in observational studies for causal effects. Biometrika, 70(1), 41-55. https://doi.org/10.1093/biomet/70.1.41

Shipman, J. E., Swanquis, Q. T., \& Whited, R. L. (2017). Propensity score matching in accounting research. The Accounting Review, 92(1), 213-244. https://doi.org/10.2308/accr-51449

Shleifer, A., \& Vishny, R. W. (1986). Large shareholders and corporate control. Journal of Political Economy, 94(3, Part 1), 461-488. https://doi.org/10.1086/261385

Singh, P. P. (2017). Does pledging of shares by controlling shareholders always destroy firm value? Working Paper. https://doi.org/10.2139/ssrn.2989818

Stock, J. H., \& Yogo, M. (2005). Testing for weak instruments in linear IV regression. Identification and Inference for Econometric Models: Essays in Honor of Thomas Rothenberg, 80. https://doi.org/10.1017/CBO9780511614491.006

Subramaniam, V., Tang, T. T., \& Yue, H. (2011). Firm structure and corporate cash holdings. Journal of Corporate Finance, 17(3), 759-773. https://doi.org/10.1016/j.jcorpfin.2010.06.002

Wang, Y. C., \& Chou, R. K. (2018). The impact of share pledging regulations on stock trading and firm valuation. Journal of Banking \& Finance, 89, 1-13. https://doi.org/10.1016/j.jbankfin.2018.01.016

Xu, N., Chen, Q., Xu, Y., \& Chan, K. (2016). Political uncertainty and cash holdings: Evidence from China. Journal of Corporate Finance, 40, 276-295. https://doi.org/10.1016/j.jcorpfin.2016.08.007 


\section{Appendix}

Table A.1. Variable Definitions

\begin{tabular}{|c|c|}
\hline Variable & Definition \\
\hline Cash & $\begin{array}{l}\text { Cash holdings, the ratio of cash and cash equivalents to net assets (total assets minus cash and cash } \\
\text { equivalents) }\end{array}$ \\
\hline $\log ($ Cash $)$ & Cash holdings, the logarithm of Cash. \\
\hline$\Delta$ Cash & $\begin{array}{l}\text { Change in cash holdings, the ratio of (cash and cash equivalents in year } t \text { minus cash and cash } \\
\text { equivalents in year t-1) to total assets in year } t-1 \text {. }\end{array}$ \\
\hline Pledge & $\begin{array}{l}\text { Share pledging ratio, the number of shares pledged by controlling shareholders as a percentage of } \\
\text { total shares by the end of a given year. }\end{array}$ \\
\hline Pledge_Dummy & $\begin{array}{l}\text { Share pledging dummy, a dummy variable that equals to one if the fraction of share pledging is } \\
\text { larger than zero by the end of a given year, and zero otherwise. }\end{array}$ \\
\hline Pledge_Top & $\begin{array}{l}\text { Share pledging ratio, the number of shares pledged by controlling shareholders as a percentage of } \\
\text { total shares owned by the top } 10 \text { largest shareholders by the end of a given year. }\end{array}$ \\
\hline Size & Firm size, the natural logarithm of total assets. \\
\hline Leverage & Firm leverage, the ratio of total debt to total assets. \\
\hline $\log ($ Age $)$ & Firm age, the logarithm of one plus the current year, minus the listing year. \\
\hline $\mathrm{MB}$ & Market-to-book ratio, the ratio of the market value of equity to the book value of equity. \\
\hline Opcf & Operating cash flow, the ratio of net cash flows from operating activities to total assets. \\
\hline Cashflow & $\begin{array}{l}\text { Operating cash flow, the ratio of net cash flows from operating activities in year } t \text { to total assets in } \\
\text { year } t-1 \text {. }\end{array}$ \\
\hline Gsale & Sales growth, the ratio of (total sales in year $t$ minus total sales in year $t-1$ ) to total sales in year $t-1$. \\
\hline Capex & Capital expenditures, the ratio of capital expenditures to total assets. \\
\hline Cf_Sigma & Cash flow volatility, the standard deviation of $O p c f$ in the industry in a given year. \\
\hline Div & $\begin{array}{l}\text { Dividend payout, a dummy variable equals to one if the firm pays out cash dividend in a given year, } \\
\text { and zero otherwise. }\end{array}$ \\
\hline Div_Asset & Dividend payout, the ratio of cash dividends to total assets. \\
\hline Div_Sale & Dividend payout, the ratio of cash dividends to total sales. \\
\hline Top1 & Ownership concentration, the fraction of shares held by the largest shareholder. \\
\hline Treat & $\begin{array}{l}\text { An indicator variable of the treatment group that equals to one if a firm's amount of pledged shares } \\
\text { increase the most (in the top three deciles of the sample) around the regulatory change in 2013, and } \\
\text { zero otherwise. }\end{array}$ \\
\hline Post & $\begin{array}{l}\text { An indicator variable of the regulatory change in } 2013 \text { that equals to one if it is year } 2013 \text { or after, } \\
\text { and zero otherwise. }\end{array}$ \\
\hline Labor & $\begin{array}{l}\text { Labor intensity, the ratio of the number of employees (times } 10^{\wedge} 8 \text { ) to total assets. I measure this } \\
\text { variable using the data of } 2007 \text {. }\end{array}$ \\
\hline Post08 & $\begin{array}{l}\text { An indicator variable of the Labor Contract Law that equals to one if it is year } 2008 \text { or after, and zero } \\
\text { otherwise. }\end{array}$ \\
\hline$\Delta W k$ & $\begin{array}{l}\text { Changes in net working capital, the ratio of [working capital minus working capital in year } t-1 \text { minus } \\
\text { (cash and cash equivalents in year } t \text { minus cash and cash equivalents in year } t-1 \text { )] to total assets in } \\
\text { year t-1. }\end{array}$ \\
\hline$\Delta S d e b t$ & $\begin{array}{l}\text { Changes in short-term debt, the ratio of (current debt in year } t \text { minus current debt in year } t-1 \text { ) to total } \\
\text { assets in year } t-1 \text {. }\end{array}$ \\
\hline
\end{tabular}

\section{Copyrights}

Copyright for this article is retained by the author(s), with first publication rights granted to the journal.

This is an open-access article distributed under the terms and conditions of the Creative Commons Attribution license which permits unrestricted use, distribution, and reproduction in any medium, provided the original work is properly cited. 